\title{
THE IMPACT OF GOOD CORPORATE GOVERNANCE TO MANUFACTURING FIRM'S PROFITABILITY AND FIRM'S VALUE
}

\author{
Johanes Sumarno, Sendy Widjaja, Subandriah \\ Universitas YAI, Ministry of Religious Affair \\ j.sumarno@yai.ac.id, sendywidjaja@yahoo.com, andri_mora@yahoo.co.id
}

\begin{abstract}
This paper studied the behavior of management toward the implementation of Good Corporate Governance in Indonesia to determine whether it has any influence towards profitability and its implication to the Manufacturing Firms' value publicly listed in Indonesian Stock Exchange. There were $4 I$ corporations who met the criteria of the survey. The data were analyzed using Panel Regression with fixed effects Model. The empirical findings show that the implementation of Corporate Governance in Indonesia has a positive, significant and direct impact toward firms' profitability and firms' value. Corporate Governance principles based on OECD principles that have positive and significant impact to both profitability and Firms' Valueis Rights of Shareholders, Role of Stakeholders, Responsibilities of the Board Commissioners and Board of Directors. The principles that have significance and negative impact towards corporate profitability and value, are: Equitable treatment of shareholders and Disclosure and Transparencies. The most significant principle influencing profitability and firms' value is Disclosure and Transparencies. Profitability plays a greater role in influencing Manufacturing Firms' value in Indonesia.
\end{abstract}

Keywords: Corporate Governance; Profitability; Firm's Value; Manufacturing Firm.

\begin{abstract}
Abstrak
Penelitian ini pada dasarnya mempelajari perilaku pemimpin perusahaan manufaktur dalam implementasi Tata Kelola Perusahaan di Indonesia untuk mengetahui dampaknya terhadap keuntungan dan nilai pasar dari perusahaan yang terdaftar di Bursa Efek Indonesia. Terdapat 4I perusahaan yang memenuhi kriteria dalam penelitian ini. Data akan dianalisis menggunakan regresi panel dengan model efek tetap. Hasil penelitian empris ini menyimpulkan bahwa implementasi Tata Kelola Perusahaan di Indonesia mempunyai dampak yang positif dan signifikan terhadap keuntungan perusahaan dan nilai pasar perusahaan. Prinsip tata kelola perusahaan yang memiliki dampak signifikan dan positif terhadap keuntungan dan nilai perusahaan adalah hak Pemegang Saham, Peranan para pemangku kepentingan. Prinsip yang mempengaruhi secara negatif dan signifikan adalah: Perlakuan yang sama kepada Pemegang Saham, Keterbukaan dan Transparansi. Dari riset ini juga ditemukan prinsip OECD yang paling menentukan keuntungan perusahaan dan nilai perusahaan adalah Keterbukaan dan Transparansi. Profitabilitas memiliki peranan lebih penting dalam mempengaruhi nilai perusahaan manufaktur di Indonesia.
\end{abstract}

Kata Kunci: Tata Kelola Perusahaan; Profitabilitas; Nilai Perusahaan; Perusahaan Manufaktur

Received: May 22, 2016; Revised: August 25, 2016; Approved: September 9, 2016 
The Impact of Good Corporate Governance

Johanes Sumarno, Sendy Widjaja, Subandriah

\section{INTRODUCTION}

One major factor for Indonesian companies vulnerable to the negative impact of financial crisis in 1997 was the weakness of internal mechanisms of corporate governance. Similar to the experience of other corporate entities in the region, the failure of Indonesian companies to implement corporate governance practices carefully in the management of their companies are associated with a number of factors, including high concentration of corporate ownership and lack of transparency in the procedures for the acquisition of the company and controls. In addition to problems of inefficiency, Indonesian corporate sector is also vulnerable to the problem of risk exposure associated with more dependence on external funding, especially when there is effective oversight by the Board of Commissioners in Indonesia and inadequate monitoring by creditors (Asian Development Bank 1999).

Since the financial crises in various countries between 1997-1998 that preceded the crisis in Thailand (1997), followed by other countries, such as Japan, South Korea, Indonesia, Malaysia, Hong Kong and Singapore, which eventually turned into the Asian financial crisis, were results of poor Corporate Governance(CG) in Asian countries. The failure of some companies and the emergence of financial malpractices that occurred due to crisis is the worst evidence of the weak practice of GCG among countries. According to Pangestu and Hariyanto (Suprayitno et al. 2004), characteristics of weak practices of GCG in Southeast Asian countries, including Indonesia, are (I) the concentration of insider ownership and the power of shareholders (including the government and related parties of the center of power), (2) weak governance in financial sector, and (3) the ineffectiveness of internal regulations and the lack of legal protection for minority shareholders to deal with major shareholders and managers.

According to a research conducted by Black, et.al (2003), there is a strong and robust relationship between the implementation of GCG with the profitability of companies in South Korea and Russia (Black, 200I). These findings highlight that companies with GCG will perform better both financially and in market value. There is a need to perform a similar research in Indonesia to find out whether the result would be consistent with other parts of the world.Previous researches studied the 
relationship of Corporate Governance Index with Firm Value using linear regression. This research will explore the relationship between Corporate Governance Index, its OECD principles and Profitability in terms of Return of Assets using multiple regressions, and the scoring is from an external point of view to reduce biasness.

Based on the description above, this study will construct a Corporate Governance Index based on OECD principles adjusted with basic Indonesian corporate characteristics. The five parts of Corporate Governance Index will include Rights of Shareholders, Equitable Treatment of Shareholders, the Role of Stakeholders in Corporate Governance, Disclosure and Transparency, and Responsibilities of the Board. The Corporate Governance Index will be compared with the firms' financial performance and market value. Therefore, this study will answer the following problems, they are: first, Do investors value the implementation Corporate Governance using OECD principles be significant in Indonesia in determining profitability and firms' value?Second, What are the most important OECD principles influencing profitability and firms' value in Indonesia?

\section{METHODS}

This study use a combination of qualitative and quantitative methods of hypothesis testing data influencing corporate governance elements of the Return on Assets (ROA) and Tobins $Q$ on the 100 Companies listed in Kompas 100 between 2007-20 II, excluding the banking and financial institutions which is the majority of the transactions and market capitalization in Indonesia. Qualitative methods were used to analyze the primary data of independent variables (exogenous) consisting of elements of Corporate Governance Transparency, they are: rights of shareholders, equitable treatment of shareholders, role of stakeholders in corporate governance, disclosure and transparency, responsibilities of the board. These data were obtained by way of survey questionnaires filled by 2 people analyzing the contents of annual report 2007$201 \mathrm{I}$ obtained from Bursa Efek Indonesia (Indonesian Stock Exchange), relevant corporate websites and news from Kontan.co.id. While the quantitative methods used to analyze secondary data dependent variables (endogenous) are Return on Assets (ROA)and Tobins' $Q$. This research will be using data panel to compute all the data obtained and will be using $E$ Views as a computer software tool to organize the data. 
The Impact of Good Corporate Governance

Johanes Sumarno, Sendy Widjaja, Subandriah

The observation of data was conducted 5 times by 5 different individuals to minimize biasness and error. The qualifications of those collecting the data were final year students of Accounting major students of undergraduate students and post graduate students, to verify the data using the questionnaire built using the OECD standard of Good Corporate Governance.

The choice of research sample was to use purposive sampling method, which is to use certain criteria in the sample selection, the criteria of sampling choice in this research is: First, Listed in Indeks Kompas 100 in December 2013. Second, the chosen companies have complete annual reports and other supporting documents available for public access that can be used for the purpose of this research.

The questionnaire to acquire Corporate Governance Index based on the 5 OECD principles are: First, variables include Rights of shareholders (I5 questions) principles A-.Second, equitable treatment of shareholders (10 questions) -principles B.Third, rights of stakeholders in corporate governance (4 questions) -principles C.Fourth, disclosure \& transparency (30 questions) -principles D-.Fifth, responsibilities of the board of co mmissioners and board of directors (2I questions) -principles E-. Each question would contain a yes or no response. Each yes response gets a score of I and each no gets a score of 0 . Each variable contain in each section is a sum of observation found in the annual reports and data available each company. Based on the sample criteria above, only $4 \mathrm{I}$ companies in this research will be further analyzed.

The method that used in this research is panel regression. The equation for the analyze the impact of GCG principle on firm's protability can be written as follow:

$$
\mathrm{ROA}_{i \mathrm{t}}=\alpha+\beta_{1} \mathrm{RS}_{\mathrm{it}}+\beta_{2} \mathrm{ETS}_{\mathrm{it}}+\beta_{3} \mathrm{ROS}_{\mathrm{it}}+\beta_{4} \mathrm{DT}_{\mathrm{it}}+\beta_{5} \mathrm{RBB}_{\mathrm{it}}+\varepsilon_{\mathrm{it}}
$$

Where: ROA is return on asset; RS is rights of shareholders; ETS is equitable treatment of shareholders; ROS is role of shareholders; DT is disclosure and transparencies; RBB is role board of director (BOD) and board of commisioner $(\mathrm{BOC})$.

Besides that, we are going to analyze the impact of five principles to Firm's value, the equation can be written as follow:

$$
\mathrm{TQ}_{\mathrm{it}}=\alpha+\beta_{1} \mathrm{RS}_{\mathrm{it}}+\beta_{2} \mathrm{ETS}_{\mathrm{it}}+\beta_{3} \mathrm{ROS}_{\mathrm{it}}+\beta_{4} \mathrm{DT}_{\mathrm{it}}+\beta_{5} \mathrm{RBB}_{\mathrm{it}}+\beta_{6} \mathrm{ROA}_{\mathrm{it}}+\varepsilon_{\mathrm{it}}
$$

Where: TQ is Tobin Q; RS is rights of shareholders; ETS is equitable treatment of shareholders; ROS is role of shareholders; DT is disclosure and transparencies; RBB is 
role board of director (BOD) and board of commisioner (BOC). ROA is return on asset.

There are three model that can be used in panel regression, such as: common effect model, fixed effect model, and random effect model. To find the best model between common effect and fixed effect, we used Chow test. For the best model between fixed effect and random effect, we used Hausman test. For the best model between common effect and random effect, we used Lagrange Multiplier test.

\section{RESULT AND DISCUSSION}

\section{Good Corporate Governance and Firm's Profitability}

Based on the paired tests of 3 data panel regression models, as indicated in Table I can be concluded that fixed effect model in the data panel regression is appropriately used to further analyze 5 principles $(A, B, C, D$, dan E) of corporate governance on ROA of 4 I corporations in Indeks Kompas for period 2007-20I2.

Table I. Panel Data Regression Model Test Conclusion

\begin{tabular}{llll}
\hline No & Methods & Tests & Results \\
\hline I & Chow-Test & Common Effect vs Fixed Effect & Fixed Effect \\
2 & Lagrange Multiplier (LM-test). & Common Effect vs Random Effect & Random Effect \\
3 & Hausman Test & Fixed Effect vs Random Effect & Fixed Effect
\end{tabular}

Data panel regression estimate with fixed effect model proves that corporate governance principles, they are principles $A, B, C, D$, and $E$ partially impact ROA performance significantly at 95 percent confidence level. For $F$ test shows that 5 principles of corporate governance simultaneously and significantly impact ROA performance. Meanwhile for the goodnes of fit test, shows that determining coefficient $\mathrm{R}^{2}$ of 0.9540 , which means that 5 corporate governance principles can explain variation of ROA by 95.40 percent, while the remaining 4.60 percent can be explained by other factors not included in this model.

Corporate Governance principle A with the coefficient estimator $B_{1}=0.4499$ impact ROA positively and significantly, where $p$ value t-statistic $(0.0009)$ is less than $\alpha$ $=0,0 \mathrm{I}$ which means that $\mathrm{H}_{0}$ is rejected. The interpretation of $B_{1}=0.4499$ is when there is improvement of corporate governance $A$ by $10 \%$ then the ROA will increase by $4.50 \%$. This empirical finding is consistent with the research hypothesis that states corporate governance A positively impact the profitability performance measured by 
ROA of $4 \mathrm{I}$ corporations in $4 \mathrm{I}$ corporations in Indeks Kompas 100 for period 20072012.Corporate Governance Principle B with coefficient estimator $B_{1}=-1.5878$ impact the ROA negatively and significantly, where $p$ value t-statistic $(0.0046)$ is less than $\alpha=0.05$ which means $H_{0}$ is rejected. The interpretation of $B_{1}=-1.5878$ is when there is improvement of corporate governance principle B by $10 \%$ then the corporate ROA will decrease by 15.88 percen. This empirical finding is different from the research hypothesis that states that corporate governance principle B positively impact the profitability of ROA of 41 corporations in Indeks Kompas 100 for period 2007 2012.

Table 2. GCG and Firm's Profitability

\begin{tabular}{ccccc}
\hline Variable & Coefficient & Std. Error & t-Statistic & Prob. \\
\hline C & 19.71892 & 0.939739 & 20.98339 & 0.0000 \\
RS (A) & 0.444989 & 0.182449 & 2.438982 & 0.0156 \\
ETS (B) & -1.587838 & 1.056775 & -3.502532 & 0.0046 \\
ROS (C) & 1.533926 & 0.397136 & 3.862471 & 0.0002 \\
DT (D) & -3.386388 & 1.095304 & -3.091734 & 0.0023 \\
RBB (E) & 0.562175 & 0.200112 & 2.809301 & 0.0055 \\
\hline R-squared & 0.953960 & F-statistic & 89.47391 \\
Adjusted R-squared & 0.943298 & Prob(F-statistic) & 0.000000
\end{tabular}

Corporate governance principle $C$ with coefficient estimator $b_{1}=1.5339$ impact the ROA performance positively and significantly where $p$ value t-statistic (0.0580) is less than $\alpha=0.10$, which means that $H_{0}$ is rejected. The interpretation for $B_{1}=1.5339$ is when there is improvement of corporate governance principle B by $10 \%$ then corporate ROA will increase by $15.34 \%$. This empirical finding is consistent with the research hypothesis that Corporate Governance $C$ positively impact the ROA of 4 I corporations in Indeks Kompas 100 for period 2007-20I2.

Corporate Governance principle $D$ with the coefficient estimator $B_{1}=$ 3.38649 did not impact the ROA performance where probability value t-statistic $(0.1210)$ is greater than $\alpha=0.05$, which means that $H_{0}$ is don't rejected. This empirical finding is different from the research hypotesis that states corporate governance principle $D$ positively and significantly impact the profitability performance measured by ROA of 4I corporations in Indeks Kompas 100 for period 2007-20I 2.

Corporate Governance Principle E with coefficient estimator $b_{1}=0.5622$ impact the ROA performance positively and significantly, which means $H_{0}$ is rejected. 
Interpretation for $b_{1}=0.5622$ is when there is increase value from corporate governance principle $\mathrm{E}$ by 10 percent then the performance ROA will increase by 5.62 percent. This empirial finding is consistent with the research hypothesis that Corporate Governance Principle E has positive impact on the profitability measured by ROA of 4 I corporations Indeks Kompas 100 for period 2007-20I2.

The use of fixed effect model for data panel regression can show variation in the constants of $4 \mathrm{I}$ corporations that become the samples of this research, though the coefficient regressor remains the same. Fixed effect meant in this research is that each corporation has a constant value that remains the same for different period of time (time invariant). The estimate of data panel regression data panel equation for each of the corporation shown in the equation 5.44 sampai 5.83 . From the $4 \mathrm{I}$ data panel regression equation for each company (equation $5.44-5.83$ ) can be concluded as the following: First, corporation that has the highest average improvement of ROA performance during period 2007-2012 is perusahaan PT. Gas Negara (Persero) Tbk $(\mathrm{SMRA})$ with total Constant value $\left[\mathrm{C}_{\mathrm{i}}+21.9198\right]=6.9869+19.7189=35.7251$. Second, corporation that has the lowest performance of ROA for period 2007-20I2 is Mayora Indah Tbk (MYOR) with total constant value of $\left[C_{i}+21,9198\right]=-8.8510+$ $19.7189=10.8679$.

This empirical finding in Indonesia is in line with CLSA research finding in 2002 where higher Corporate Governance Index eventually translates to higher firms' value. Managers who believe the corporations will go well will purchase stocks that can be the motor of increasing the value of corporations like in Japan (Morch et al, 2000), and other countries (Khan et al, 2009, Frakes 2007, Jiao 20I0).

Corporate Governance principle for equitable treatment of shareholders (B) effected ROA negatively and significantly. This can be attributed to higher cost associated to maintain a large number of stockholders of public companies that may change their ownership frequently. Corporate Governance principle for equitable treatment of shareholders (B) did not have a significant effect on Tobins' $Q$. This empirical finding is consistent with the finding of Lukviarman (200I) of corporations in Indonesia do not have the mechanism for addressing minority stockholders expectation, as the majority of the companies are owned by majority stockholders 
The Impact of Good Corporate Governance

Johanes Sumarno, Sendy Widjaja, Subandriah

who are mostly family or the government. Musnadi (2006) found that excessive control from majority stockholders hinder management's creativity.

Frakes (2007) found that the institutional ownership level in a large proportion would effect the value of firm positively. Based on this finding, the larger the instutional ownership, the more effective management performance will be. There were three hypothesis for the relationship between instutional ownership and the value of firm. The first interpretation was the efficient monitoring hypothesis. This hypothesis revealed that individual investors and inside owners with low ownership of stocks (minority) had a tendency to lend its voting power to institutional investors to control the performance of management. Majority institutional investors would be on the side of minority stockholders when they share a common interest, particularly in obtaining economic incentive both in the long run (dividend) and short run (abnormal stock return). This action would impact on the growth of corporate value shown by the increase of stock price.

The second interpretation was the strategic alignment. Different from the first one, this hypothesis stated that majority institutional investors had a tendency to compromise, or on the side of management, ignored the interest of minority stockholders. The assumption that the management often takes actions and makes policies that were less than optimal and tending to personal interest, causing the strategic alliance between majority institutional investors and the management, is negatively responded by the public. This would lead to the decrease of stock price. The third interpretation was the conflict of interest hypothesis. This hypotheses basically shared similar concept with the second hypothesis, which was majority institutional investor to reduce conflict by compromising and allying with the management.

The three aforementioned interpretations have separated the explanations of positive relationship from the institutional relationship with the value of firm. This separation is finally bringing a conclusion to the inconsistent relationship between institutional ownership with the value of firm. Mak and Kusnadi (2005) found that instituitional ownership did not have significant relation to the value of firm. The previous researches related to Principle $B$ had no significant relationship with value of the firm Hypothesis 3 in Indonesia and U.S.A. 
Corporate Governance principle of role of stakeholders in corporate governance (C) have positive and significant effects on ROA, which is in support of the stakeholder theory (Freeman, 1984 and Mitchell, et.al, 1997) that states a corporation needs to work, identify its stakeholders to ensure long term sustainable attainment of corporations goals. This empirical finding also support Hofstede's finding that Indonesia is a highly collectivist country (Widjaja, 20I0) so the support of community is essential to achieving a win win relationship.

Corporate Governance principle responsibilities of the board of Commissioners and board of Directors $(E)$ effect the profitability performance of ROA positively and significantly. This is consistent with the findings of Gisbert and Navallas (20/3) for Spanish corporations when a manager understands the principal is monitoring their activities there is more disclosure. Ho and and Wong (200I), Eng and Mak (2003) found that companies listed in Hong Kong Stock Exchange have positive and significant relation healthy ratio of non executive independent directors, block institutional ownership, board size and lower director ownership on the board.

\section{Good Corporate Governance and Firm's Value}

Next, we are going to analyze the impact of five GCG principles to the Tobin $\mathrm{Q}$ value. Data Panel regression model estimate with fixed effect model shows that principles A, B, C, D, E of Corporate Governance and ROA affect the firms' value Tobin's $Q$ significantly at 95 percent level of confidence. For $\mathrm{F}$-test shows that the 5 principles of corporate governance and profitability ROA significantly affect the firms' value measured by Tobin's $Q$. For the goodness of fit test, shows that the determining coefficient $R^{2}$ at 0.9332 , which means that the variation of corporation valuation measured by Tobin's $\mathrm{Q}$ can be explained by the 5 principles of corporate governance and profitability performance by 93.32 percent, while the rest 6.68 percent can be explained by other factors not included in this model.

Principle $A$ of Corporate Governance with the estimator coefficient $B_{1}=$ 0.3224 partially affect the firms' value measured by Tobin's q positively and significantly at 95 percent level of confidence where $p$ value t-statistic $(0.0173)$ is less than $\alpha=0.05$ which means that is $\mathrm{H}_{0}$ rejected. For $B_{1}=0.3224$ explanation is when principle $A$ from Corporate Governance increases by 10 pecent, then the firms' value will go up by 
The Impact of Good Corporate Governance

Johanes Sumarno, Sendy Widjaja, Subandriah

3.224 percent. This empirical finding is consistent with the research hypothesis that principle A is positively affecting the firms' value by Tobin's $q$ at the $4 \mathrm{I}$ corporations in Indeks Kompas 100 for period 2007-20I2.

Table 3. GCG and Firm's Value

\begin{tabular}{ccccc}
\hline Variable & Coefficient & Std. Error & t-Statistic & Prob. \\
\hline C & 15.77765 & 11.19910 & 4.408831 & 0.1605 \\
RS (A) & 0.322419 & 0.178117 & 2.810154 & 0.0019 \\
ETS (B) & -0.316580 & 1.021175 & -2.310015 & 0.0169 \\
ROS (C) & 0.454706 & 0.390879 & 2.163292 & 0.0002 \\
DT (D) & -1.065785 & 1.062951 & -3.002666 & 0.0073 \\
RBB (E) & 0.011338 & 0.193349 & 3.058642 & 0.0033 \\
ROA & 0.294055 & 0.276885 & 2.062010 & 0.0096 \\
\hline R-squared & 0.933201 & F-statistic & 57.09582 \\
Adjusted R-squared & \multirow{2}{*}{0.916856} & Prob(F-statistic) & 0.000000 \\
\hline Principle & B from & corporate & governance with coefficient & estimator
\end{tabular}

$=-0.3166$ partially negatively and significantly affect firms' value measured by Tobins'Q. This empirical finding supports the research hypothesis that states Principle B from Corporate Governance negatively and significantly affect the firms' value measured by Tobin's $q$ at $4 \mathrm{I}$ corporations in Indeks Kompas 100 during period 2007-2012. Principle C from corporate governance with coefficient estimator $B_{3}=0.4546$ partially positively and significantly affect firms'value measured by Tobins'Q. This empirical finding supports the research hypothesis that states Principle C from Corporate Governance positively affect the firms' value measured by Tobin's $q$ at $4 \mathrm{I}$ corporations in Indeks Kompas 100 during period 2007-20I2.

Principle D from corporate governance with coefficient estimator $B_{4}=-1.0658$ partially significantly and negatively influence firms' value measured by Tobins' $Q$. This empirical finding supports the research hypothesis that states Principle D from Corporate Governance negatively affect the firms' value measured by Tobin's $q$ at $4 \mathrm{I}$ corporations in Indeks Kompas 100 during period 2007-2012. Principle E from corporate governance with coefficient estimator $b_{5}=0.01 \mathrm{I} 3$ significantly and positively partially influence firms' value measured by Tobins'Q. This empirical finding supports the research hypothesis that states Principle E from Corporate Governance positively 
affect the firms' value measured by Tobin's q at $4 \mathrm{I}$ corporations in Indeks Kompas 100 during period 2007-20I2.

Profitability performance measured by ROA with coefficient estimator $B_{6}=$ 0.294 I significantly and positively influence firms' value measured by Tobins'Q. This empirical finding supports the research hypothesis that states Profitability performance ROA positively affect firms' value measured by Tobin's q at $4 \mathrm{I}$ corporations in Indeks Kompas 100 during period 2007-20I2.

From the 4I fixed effect data panel regression for each corporation (equation 5.208 - 5.247) can be concluded as the following: First, company that has the highest Firms' value by Tobins'Q during the period of 2007-20I2 is PT.Bumi Resource Tbk (BUMI) with Constant value $\left[C_{i}+89,9562\right]=3,6355+15,7776=19.4131$. Second, company that has the lowest average in Firms' value by Tobins'Q for the period 20072012 is PT Mayora Indah Tbk (MYOR) with total constant value $\left[C_{i}+89,9562\right]=-$ $8,6463+15,7776=7.1313$.

This empirical finding supports the research by Bebchuck et al (2004) found that honoring the rights of stockholders lead to higher firms' valuation. Stiglitz (1985) that states majority institutional investors provide increased ability to control the power of voice or representations on Board of Directors.

Corporate Governance principle disclosure and transparency (D)negatively and significant impact on ROA, Tobins' $Q$. Out of the 5 principles. This principle is the most influential one shown by the largest coefficient values. This is possible due to the fact that many of the companies included in the sample of Indonesian Manufacturing firms in Kompas 100, were family business groups in Indonesia, where the family business patriarchs still have the final say of what is to be implemented in the corporations. This unexpected finding is consistent with Tabalujan (2002) concept of Patrimonialism where there is a deviation between the formal law and implementation in Indonesia, because of the opportunistic attitude of business people (Williamson, 1988). This empirical finding is also similar to the findings in Hong Kong researched by Leung and Horwitz (2004) that concentrated ownership is correlated with low voluntary disclosure. In this case, the concentrated ownership is the shares owned by the families listed in Indonesian Stock Exchange. Secondly, IFRS were to be implemented in Indonesia starting from 2012. The annual reports in this study only 
The Impact of Good Corporate Governance

Johanes Sumarno, Sendy Widjaja, Subandriah

covers the years of 2007-2012. IFRS would require public listed companies to disclose sufficiently. If more years to be included, it is likely that these companies will be more transparent that the samples in this research.

Corporate Governance principle for responsibilities of the board of Commissioners and board of Directors (E) positively and significantly impact on firms' value Tobins' $Q$. Corporate Governance Index positively and significantly affect profitability performance as indicated by the measurement of ROA and the firms' value expressed by Tobins' $\mathrm{Q}$. The notion that Corporate Governance Index has significant and positive implication with profitability ROA is consistent with the research findings of Brown and Caylor (2004), Mormahadi (2005). ROA directly effect firms' values significantly and positively directions.

This is consistent with the Assymetry theory and agency theory that state there is an information congruence between the owners and managers who run the company, which may have different or even conflicting points of interests. This empirical finding supports the validity of these theories in Indonesian public listed companies in Indeks Kompas 100 for period 2007-2012, as Lukviarman (200I) found that many companies do not apply Corporate Governance in Indonesia because there is insufficient law enforcements and supporting agencies.

Morck et al. (1988) and McConnell and Servaes (1990) documented a nonlinear relation between managerial ownership to the value of firm. The ownership of firm management aligned the interest of management inside the company with the interests of outside stockholders, increasing value. However, up to a certain degree of ownership as inside managerial ownership increases the entrenchment effects (opacity) and of inside ownership dominates; and higher inside management ownership was associated with lower firm value.Bhagat et al. (2004) did not find any evidence supporting positive correlation between the concentrations of ownership with the value of firm in the stock market. His research found that Hypothesis 3 Principle D was not significantly affecting Firm's value.

Corporate Governance Index negatively and significantly affect profitability performance of firms' value expressed by Tobins' $Q$, is related to the fact that Disclosure and transparencies at Hypothesis 3.4 is significantly negatively related to Indonesian manufacturing firms' value. This finding different from the findings from 
Black et.al (2003) of corporations in South Korea that proved better corporate governance index leads to a higher corporate value and Cheung et al (2007) for corporations listed in Hong Kong. We can attribute this due to the fact that IFRS had just been mandatorily implemented for Indonesian public companies starting 2012. Thus, before that time Corporate Governance in Indonesian Manufacturing firms' who are predominantly family business were not implemented. This is also reflected with the very low coefficient of Corporate governance Index signalling the weak implementation of Corporate Governance in Indonesia.

From this result, the most important principle of Corporate Governance influencing both the manufacturing firms' profitability and manufacturing firms' value is disclosure and transparencies, followed by equitable treatment of shareholders. This means the improvement of these principles implementation in Indonesia will fundamentally strengthen the corporate governance implementation in Indonesia. Besides that, we learn that Profitability plays a more vital role in influencing the Indonesian manufacturing firms' value compared to Corporate Governance Index that represent the cumulative implementation of corporations.

Silveira and Barros (2007) research the quality of corporate governance in relation to the value of firm for I54 Brazillian companies listed in Stock Exchange in 2002. They prepared a corporate governance index as a GCG indicator. This finding wass similarly shared with the research findings of Beltratti (2005); Vintila and Gherghina (20I2); and Fallatah and Dickins (20I2). Their findings also supported that Hypothesis 3 \& 4 had positive and significant related to firms' value. Black et al. (2003) created a corporate governance index using a survey conducted by Korean Stock Exchange find that firms with better corporate governance index have a higher market value. Unfortunately, this survey relied on the selection of companies' responses that could have bias in the data.

Cheung et al. (2007) examine the relationship between corporate governance and the value of firm, listed in Hongkong, based on OECD principles of corporate governance and the code of best practices. They constructed a corporate governance index for Hongkong listed companies. The empirical evidence shows that a company's value was positively related to overall corporate governance index. This research summarizes that GCG is equal to value maximization. 
The Impact of Good Corporate Governance

Johanes Sumarno, Sendy Widjaja, Subandriah

Chai et al (2007) empirically proven that high quality corporations can give signals to the market that would lead the stock price decrease. Miglo (2007) used a mathematical approach using the assymetric information theory. Information separates the understanding of high earning corporations from low earning ones. Those that have high earnings would tend to use debt as a source of financing and those of low earnings will issue shares to the public.

\section{CONCLUSION}

Model I from this research concludes and supports the hypothesis that rights of shareholders significantly and positively influence ROA. The finding also support that Equitable Shareholders significantly and negatively influence ROA. The research concludes that Role of Stakeholders in Corporate Governance Significantly and Positively influence ROA. Disclosure and Transparency significantly and negatively influence ROA. Responsibilities of The board of Commissioners and Board of Directors significantly and positively influence ROA. The conclusions answer both the research objectives and problem identification mentioned earlier.

Model 2 findings conclude that the hypothesis that Rights of Shareholders positively and significantly influence Firms' value using Tobins' $Q$ is determined by the stock prices, and it is determined by supply and demand. The model also postively and significantly influence Tobins'Q. Equitable Treatment of Shareholders negatively and significantly influence Firm's value using Tobins'Q. Role of Stakeholders in Corporate Governance Significantly and positively influence Tobins' $Q$. Disclosure and Transparency significantly and negatively influence Tobins'Q. Responsibilities of Board of Commissioners and Board of Directors significantly and positively influence Tobin's Q. ROA positively and significantly influence Tobins' $Q$. These conclusions answers the research questions and objectives mentioned in the beginning of the research. 


\section{REFERENCES}

Adams, R.B. \&H. Mehran, (2003).Is Corporate Governance Different for Bank Holding Companies? FRBNY Economic Policy Review.Vol. 9, pp. I23-I42.

Agrawal, A. \&C.R. Knoeber. (1996). Firm Performance and Mechanisms to Control Agency Problems between Managers and Shareholders. Journal of Financial and Quantitative Analysis.Vol3 I, pp.377-97.

Alonso, P.D.A.\&E.V. Gonzalez, (2008). Corporate Governance in banking: The role of the board of directors.Journal of Banking \& Finance.Vol. 32,pp. 2570-2580.

Capulong, M.V, et.al (ed). (1999). Corporate Governance and Finance in East Asia. A Study of Indonesia, Republic of Korea, Malaysia, Philippines, and Thailand.Vol. I and Vol. 2. Asian Development Bank.

Bai, C. E.et.al, (2004). Corporate Governance and Market Valuation in China.Journal of Comparative Economics.Vol. 32, pp. 599-6I6.

Bebchuk, L.A. \&M.J. Roe. (1999). A Theory of Path Dependence in Corporate Ownership and Governance. Stanford Law Review. Vol. 52 (127), Pp. 127-169.

Bhagat, S.et.al.(2004). The Non Correlation between Board Independence \& Long Term Firm Performance. Journal of Financial Research.Vol. 27, pp. I-30.

Black, B.et.al. (2003). Does Corporate Governance Affect Firm Value (Evidence from Korea).USA: Stanford Law School.

Black, B. (200I). The Corporate Governance Behavior and Market Value of Russian Firms. Emerging Market Reviews.Vol. 2, pp.89-108.

Brown, L. \&M. Caylor, M. (2006).Corporate Governanceand Firm Operating Performance.Journal of Accounting and Public Policy. Vol. 25, pp. 409-434.

Cheung, Y. L. et.al. (2007). Do Investors Really Value Corporate Governance? Evidence from the Hong Kong Market.Journal of International Financial Management \& Accounting.Vol. 20, pp. I21-130.

Cheung, Y.L.et.al. (20I3). Corporate Social Performance, Firm Valuation \& Industrial Difference: Evidence from Hong Kong. Journal of Business Ethics. Vol. I I4 (4), Pp. 625-631.

Fallatah\&Dickins (2012), Corporate Governance \& Firm Performance \& Value in Saudi Arabia.African Journal of Business Management. Vol 6 (36), pp I0025-I0034.

Freeman, R.E. (1 984). Strategic Management: A stakeholder approach. Boston: Pitman. 
The Impact of Good Corporate Governance

Johanes Sumarno, Sendy Widjaja, Subandriah

Khan, M.et.al. (20I2). Mutual Fund Trading Pressure: Firm Level Stock Price Impact \& Timing of SEOs.The Journal of Finance.Vol. 67 (4), pp. I37|-I395.

Lukviarman, N. (200I). Key Characteristics of Corporate Governance: The Case of Indonesia.Working Paper, No. OI-0I, Graduate School of Business, Curtin University of Technology, Perth.

Miglo, A. (2007). Debt Equity Choice as a Signal of Earnings Profile Over Time.Quarterly Review Economics and Finance, Vol. 47 (I), Pp.69-93.

Mitchell, R.et.al. (1997). Toward a Theory of Stakeholder Identification and Salience: Defining the Principle of Who and What Really Counts. Academy of Management Review.Vol.22 (4), 853-886.

Stiglitz, J. (1985). Credit Markets and the Control of Capital.Journal of Money, Credit and Banking, Vol. 17, I33-I52.

Tabalujan, B.S. (2002). Why Indonesian Corporate Governance Failed-Conjectures Concerning Legal Culture, Columbia Journal of Asia Law, Vol. I5 (2), Pp. I4I-I7I.

Williamson, O.E. (1985).The Economic Institutions of Capitalism; Firms, Markets, Relational Contracting. New York: The Free Press. 